\title{
Editor's introduction to the Research Handbook on the Brussels Ibis Regulation Peter Mankowski
}

\section{THE BRUSSELS IBIS REGULATION: THE MAGNA CARTA OF INTERNATIONAL PROCEDURAL LAW IN EUROPE}

Regulation (EU) No 1215/2012, ${ }^{1}$ the Brussels Ibis Regulation, ${ }^{2}$ is the magna carta,${ }^{3}$ the heart, ${ }^{4}$ the cornerstone of international procedural law in Europe, at least in EU Europe. Its eminence can be easily ascertained by every practitioner even remotely concerned with cross-border work in Europe. However arcane private international law in general might appear to practitioners, the Brussels Ibis Regulation is a well-known and renowned instrument. ${ }^{5}$ It definitely no longer needs to be introduced to anyone; it is an old acquaintance that has conquered and permeated even daily practice. Put in a wider perspective, the Brussels Ibis Regulation is one of the fundamental Acts for the internal market and its functioning in practical terms. ${ }^{6}$ The Brussels I/Ibis system celebrated its 50th anniversary in 2018..$^{7}$ It has long been recognized and hailed as a formidable success story. Yet it is a living system. The transgression from the Brussels Convention of 1968 (plus not less than four Accession Conventions of 1978, 1982, 1989 and 1996, not even counting the 'Parallel' Convention of Lugano of 1988) to the Brussels I Regulation of 2001 (plus the 2007 Lugano Convention) and eventually the Brussels Ibis Regulation of 2012 is ample evidence for this contention. Without innovation and constant revision, something initially progressive could easily morph into a slightly but increasingly dated standstill. The constant growth in cross-border lawsuits and in the cross-border recognition and enforcement of judgments within the EU triggers the necessity for a reliable and

1 Regulation (EU) No 1215/2012 of the European Parliament and of the Council of 12 December 2012 on jurisdiction and enforcement of judgments in civil and commercial matters (Recast), OJ EU 2012 L 351/1.

2 'Brussels I Regulation (recast)', 'Brussels I Regulation (new)', 'Brussels Ia Regulation' and 'Recast Brussels I Regulation' are the most common synonyms. Of these, 'Brussels I Regulation (recast)' has the best claim since it reflects the official title of the Regulation.

3 Peter Mankowski, Wie viel Bedeutung verliert die EuGVVO durch den Europäischen Vollstreckungstitel?, in: Festschrift für Jan Kropholler (Tübingen 2008), p.829 at 829.

4 Jan von Hein, Die Neufassung der Europäischen Gerichtsstands- und Vollstreckungsverordnung (EuGVVO), RIW 2013, 97 at 97.

5 Ulrich Magnus/Peter Mankowski, Preface to the First Edition, in: Ulrich Magnus/Peter Mankowski, Brussels Ibis Regulation (Köln 2016) p.VII.

6 Bertrand Ancel, Les cinquantes ans de la Convention de Bruxelles du 27 septembre 1968 concernant la compétence judiciaire et l'éxécution des décisions en matière civile et commerciale, REDI 70 (2018) (1), 13 at 13.

7 See in particular the celebratory contributions in: Geert Van Calster/Jura Falconis (ed.), European Private International Law at 50 - Celebrating and Contemplating the 1968 Brussels Convention and Its Successors (Cambridge/Antwerp 2018), in: Rev. crit. dr. int. pr. 2018, 411-580 and in: NIPR 2019, 279-372. Besides this, there was a celebratory conference, fittingly at the CJEU, on 27-28 September 2019. 
dependable system. Mutual truth might be a political maxim in the first place, ${ }^{8}$ yet generation after generation of creditors and their legal advisors have profited from the system erected on that maxim. Without mutual trust being politically (and judicially) decreed, ${ }^{9}$ the relatively free circulation of judgments between the Member States of the Brussels I/Ibis system would not have become the reality as it now exists and as creditors enjoy it every given day. Mutual trust is also the fundament for establishing uniform grounds of jurisdiction, safeguarded by a regime of lis pendens. The Brussels Ibis Regulation is a genuine and classical règlement double. Its two central parts, addressing jurisdiction on the one hand and recognition and enforcement on the other, are closely interlinked. ${ }^{10}$ The latter could not exist in its present form without the former. Uniform jurisdiction rules, and the presumption that they will be uniformly applied in all Member States, are the entry ticket to liberal modes of recognition and enforcement. Free circulation of judgments has sometimes even been elevated to the high rank of a fundamental freedom. ${ }^{11}$

\section{II. 'DARK EDGES': NEW QUESTIONS OF TODAY}

The Brussels I/Ibis system has always generated new and interesting questions, both in practical and in academic respects. There remain 'dark edges' which deserve to be fully explored. The world does not stand still and motionless, and nor do the economic or societal developments which the law necessarily needs to reflect lest it becomes out of touch with the world, its progress and its twists and turns.

\section{AN OUTLINE OF THE PRESENT RESEARCH HANDBOOK}

This Research Handbook assembles and presents a fine number of the said 'dark edges'. They can be unearthed in almost all parts of the Brussels Ibis Regulation. To add another commentary, handbook or textbook to the already impressive array of excellent commentaries, handbooks or textbooks on the Brussels Ibis Regulation would have been futile. This Research Handbook does not remotely attempt comprehensive coverage of all pertinent issues, either. Human beings should not feel tempted to do giants' works. For instance, overarching crosscutting topics which would deserve (and require) monographic treatments of their own,

8 On mutual trust and international procedural law in particular Matthias Weller, Mutual trust: in search of the future of European Union private international law (2015) 11 JPrIL 64; Matthias Weller, Mutual trust within judicial cooperation in civil matters: a normative cornerstone - a factual chimera a constitutional challenge, NIPR 2017, 1; Marek Zilinsky, Mutual trust and cross-border enforcement of judgments in civil matters in the EU: does the step-by-step approach work? NILR 2017, 115.

9 See e.g. Rolf Wagner, Zwanzig Jahre justizielle Zusammenarbeit in Ziilsachen, IPRax 2019, 185, 193.

10 See only Wolf Naturprodukte GmbH v. SEWAR spol s r.o. (Case C-514/10), ECLI:EU:C:2012:367 para. 25; Gothaer Allgemeine Versicherung AG et al. v. Samskip GmbH (Case C-456/11), ECLI:EU:C: 2012:719 para. 35 .

11 Paolo Mengozzi, L'interpretazione della convenzione di Bruxelles e i principi del diritto comunitario, Jus 1990, 92 at 92; Paolo Bertoli, 'La Brexit' e il diritto internazionale privato e pocessuale, Riv. dir. int. priv. proc. 2017, 599, 609. 
such as digitalization and the Brussels Ibis Regulation, have been left out deliberately. The goal pursued in this Research Handbook is far less ambitious. Overall, the present Research Handbook seeks to display the life, and the liveliness, of the system as demonstrated in exemplary issues. Legal certainty, flexibility, doing justice in the individual case and openness to new developments in society, business and technology need to be finely tuned.

The ordinary principle pursued in the present Research Handbook is simple: alphabetical order by (first) author's family name. Nonetheless, this outline shall attempt to assemble and regroup the topics that are discussed in detail by their wider contexts.

\section{III.1 The Place of the Brussels Ibis Regulation within the Overall System of EU law}

Many of the 'dark edges' relate to the overall system of EU law in which the Brussels Ibis Regulation of course has to find its own and proper place. Thus EU primary law and possibly discriminatory issues have their place (Johan Meeusen, Chapter 12), as does the interface with the European Insolvency Regulation ${ }^{12}$ (Antonio Leandro, Chapter 8). The advent of Brussels Ibis might also have marked the coup de grâce of the so-called 'Second Generation' of European procedural law - or has it (Mankowski, Chapter 10)? Intricate questions are raised where other Acts of EU law do not establish express jurisdiction rules, but nonetheless aim at addressing jurisdiction, particularly as regards, for political motives, the protective regimes of the Brussels Ibis Regulation. The Geoblocking Regulation ${ }^{13}$ provides the most recent and the most puzzling example of such an approach (Loacker, Chapter 9). How can the Brussels Ibis Regulation keep its backyard clean when confronted with the competing and conflicting policies of other Acts of EU law?

\section{III.2 Outer Worlds: Third States and Other Modes of Dispute Resolution}

Other contributions address the relations to the 'Outer World' - namely to Third States rather than Member States of the EU (Marongiu Buonaiuti, Chapter 11, on lis pendens), or the relation to other modes of dispute resolution than litigation (Bollée and Farnoux, Chapter 2, on the famous/infamous Recital [12] and the outcry it stirred in the arbitration community). ADR - including its still most prominent mode, arbitration - can be seen as an 'Outer World' to the Brussels Ibis Regulation, too, yet not in a territorial sense but rather a substantive and functional one.

\section{III.3 Characterization Issues}

Characterization issues from the realm of noncontractual obligations might appear - reflecting the more nuanced and more differentiated approach of the Rome II Regulation as contrasted to the rather wholesale approach of Art. 7 pt. 2 Brussels Ibis Regulation - to be focused

\footnotetext{
12 Regulation (EU) 2015/848 of the European Parliament and of the Council of 20 May 2015 on insolvency proceedings, OJ EU 2015 L 141/19.

13 Regulation (EU) 2018/302 of the European Parliament and of the Council of 28 February 2018 on addressing unjustified geo-blocking and other forms of discrimination based on customers' nationality, place of residence or place of establishment within the internal market and amending Regulations (EC) No 2006/2004 and (EU) 2017/2394 and Directive 2009/22/EC, OJ EU 2018 L 60 I/1.
} 
on torts and delicts alone. This is aptly reflected in scrutinization of culpa in contrahendo (Moura Vicente, Chapter 13) and negotiorum gestio (Dornis, Chapter 3) under the Brussels Ibis Regulation - unjust enrichment, the third in the group, is left to a future agenda. ${ }^{14}$ Do the noncontractual obligations other than tort and delict find refuge under one of the grounds for special jurisdiction, too, or are they solely remitted to the mercies of general jurisdiction under Art. 4 Brussels Ibis Regulation? And how does this comply with the 'interpretative triangle' linking the Brussels Ibis, Rome I and Rome II Regulations by virtue of Recitals (7) Rome I and Rome II Regulations? Characterization issues are thus also systematic issues.

\section{III.4 Choice of Court Agreements}

Choice of court agreements (forum selection agreements) have emerged as the dominant, all pervading instrument for practitioners in the attempt to minimize jurisdictional risks and to cater for legal certainty, for litigation planning and risk management, ${ }^{15}$ against the realm of contracts invading into that of torts, for instance. There is barely a well-drafted contract that does not contain a jurisdiction clause. However, Art. 25 (1) 1st sentence 2nd clause Brussels Ibis Regulation adopts a seemingly peculiar treatment of the material validity of choice of court agreements, isolating this issue and subjecting it to the lex fori prorogati (Franzina, Chapter 4). And where do internationally mandatory rules find their proper place in this system (Winkler, Chapter 15)?

\section{III.5 Special Modes of Lawsuits}

Nonetheless, the bulk of contributions reflects the application of the Brussels Ibis Regulation to different modes of special lawsuits, on the one hand, or the rising specialization between different industries, on the other. The regular, the ordinary lawsuit is for money between a single creditor and a single debtor. That is trite. Nonetheless, it has shaped the general view on lawsuits and their legal framework. This does not, however, liberate us from the need to take deviations from this basic model of lawsuits into proper consideration too. A system that would only master the regular case but not the 'irregular' one would be an ill-designed system missing much of its point (or perhaps would not even deserve to be called a 'system'). The regular case must not absorb all attention. Injunctive relief calls for regard (Garber, Chapter 5), as does the ever growing realm of collective redress (Arons, Chapter 1).

\section{III.6 Specialized Industries with Specialized Litigation}

IP in particular is notorious for its attempts to keep outsiders out. ${ }^{16}$ Its overcomplicated and fragmented system might not only have developed piece by piece historically but might have withstood any general harmonization or unification between the different IP rights, just in

14 On the topic Peter Mankowski, Ungerechtfertigte Bereicherung und die Brüssel Ia-VO, RIW 2017, 322; Uglješa Grušić, Unjust enrichment and the Brussels I regulation, (2019) 68 ICLQ 837.

15 Peter Mankowski, in: Thomas Rauscher, EuZPR/EuIPR, vol. I (4th ed. Köln 2016) Art. 67 Brüssel Ia-VO note 1.

16 Alexander Peukert, Vereinheitlichung des Immaterialgüterrechts: Strukturen, Akteure, Zwecke, RabelsZ 81 (2017), 158, 188-9. 
order to exert deterrence. ${ }^{17}$ It needs a true expert to fight the battles surrounding IP in European international procedural law (Heinze and Warmuth, Chapter 6).

Employers' associations and trade unions or employers and the collectivity of their employees might not be an industry in the traditional sense. Yet they form a specific kind of relationship. Collective labour issues have always been in the shadow of individual labour issues, particularly so after the advent of, first, Arts 18-21 Brussels I Regulation and, second, Arts 20-23 Brussels I Regulation. They should be awarded their own place in the spotlight (van Hoek, Chapter 7).

\section{III.7 Challenges by Particular Features of Certain Domestic Laws}

Even the Brussels Ibis Regulation does not dare ingress into the territory of procedural law as such. As a matter of division of competences under Art. 81 TFEU, the EU has to leave this to the Member States. A comprehensive unification or harmonization of procedural law in general is not even on the political agenda of the EU. Getting a title is still subject (one could even say: subjected) to the domestic law of the respective forum state. ${ }^{18}$ Direct enforcement relates to the enforcement procedures as designed and offered by the domestic law of the respective state where enforcement is sought. This law has to provide the helping hand to make the principle work. Particular features characteristic for certain domestic laws and legal orders may also occur on other levels. Pars pro toto, this is examined for the astreinte as featured in some Romanic legal orders, under the auspices of Art. 55 Brussels Ibis Regulation (Payan, Chapter 14).

17 Peter Mankowski, Orthodoxes und Häretisches zum Umfang der ausschließlichen Zuständigkeiten aus Art. 24 Nr. 4 und Nr. 3 Brüssel Ia-VO bei registrierten IP-Rechten mit Blick auf Prätendentenstreitigkeiten, IPRax 2018, 355 at 355.

18 See only Burkhard Hess/Pietro Ortolani (eds), Luxembourg Report on European procedural law I: impediments of national procedural law to the free movement of judgments (München/Oxford/Chicago/ Baden-Baden 2019). 